\title{
Analysis services administration staffing agencies offices in the areas of Majene
}

\author{
Burhanuddin \\ Dean of the Faculty of social and political sciences of the University of the West Majene Sulawesi, Indonesia \\ Email: Burhanauddinidris@yahoo.co.id
}

ARTICLE INFO

Article history:

Received, August 10, 2017

Revised, September 11, 2017

Accepted, November 292017

Keywords:

Administration

personnel

services

\section{ABSTRACT}

Standard service will need to have a clear benchmark that can use as a reference for action on every State Government organizers. Good service is how to implement the legislation as efficiently as possible, scientifically, and politically neutral. Checkout process administration promoted generally give answers that the apparatus is in running its job quite well, but in settlement of any administration is not clear. one of the factors affecting the obscurity that, because Agencies Staffing offices do not yet have an operational service standard in providing service.

Copyright () 2017 Indonesia Prime. All rights reserved.

\section{Introduction}

An important dimension in the bureaucracy of the State Government is how the apparatus or a clerk can provide the best service and quality to the community; support apparatus urgently needed in providing services that are manifested by based on convenience, attention, not favoritism, honest and responsible. To be able to achieve a good public service, then the service standard will need to have a clear benchmark that can use as a reference for action on every Government organizers (administrator) of the country. Denhard and Denhardt (2013) stated that good service is how to implement the legislation as efficiently as possible, scientifically, and politically neutral. In Act No. 25 of the year 2009 about public service described in article 1 paragraph 1 of the public service is an activity or series of activities in the framework of the fulfillment of the Ministry in accordance with the regulations for each citizen and residents of goods, services, and/or administrative services provided by the organizer of the public service. The term public service providers according to the decision of the Minister of State for Administrative Reform Number 63/KEP/M. PAN/7/2003 are government agencies. Organizers of the public service unit are the unit of work in government agencies which directly provides services to recipients of public services. The giver of the Ministry is the Official/employee of government agencies that carry out the duties and functions of the public service by the legislation.

Apparatus or officers as the backbone of the bureaucracy of Government is required to provide maximum service to the community by their needs and their significance. The Ministry provided it does not discriminate because of different ethnic groups, religions, and cultures of the people served. But the Government's bureaucratic apparatus is at the neutral position of various groups of society with emphasis on impersonal factors and away from personal factors. Authorities in providing services should be able to create a sense of Justice to those who served. This has been described by Weber who said that bureaucracy is the most rational of the known tools to carry out the control over human imperatives (Denhardt and Denhardt, 2013:233). Therefore giving the imperatives of others must be through good management. With good management of people will more easily directed, and policies will easily implement. In Act No. 5 of the year 2014 of the civil State Apparatus is 
described in article 2 that the conduct of the management and policies of the ASN based on the principle of legal certainty, professionalism, proportionality, alignment, delegation, neutrality, accountability, effective and efficient, openness, non-discriminatory, unity and unity, justice and equality, and prosperity. Related to this, Denhard (2013:83) stated that the public servants must expand the ethical boundaries of public participation in political processes in any way that they can do. Therefore, government agencies ranging from the Center up to the good that the province or district needs to set standards of services so that the activities or activities expected, i.e. the acceptance of service by public authorities or officials of the Government needs the desire of society itself. Standard service which must be accepted by the public of the apparatus has been set by the Government through the utilization of State apparatus Minister policy Number 63 the Year 2003, i.e. procedure of service, time of completion, the cost of services, products, services infrastructure and facilities, the officer's competency of service giver. Also, according to Dwiyanto et al. (2002) (in Puspita, 2004:25) system of awarding good service can be seen from the magnitude of human resources owned by the bureaucracy effectively harnessed to serve the interests of service users.

\section{Literature review}

\section{The Public Service}

The concept of stewardship can analyze as a series of activities carried out by the public bureaucracy to meet the needs of the citizens of users (citizens) who need public services. The public service is the process of fulfilling the needs and solutions to various problems that accompany the life of the community at any time by the Government or bureaucratic government in the form of goods and services provided and given when the community need or before they ask for (Subarsono, 2006:136). Therefore any public services in any form needed service standards, as a guarantee of certainty for the recipient of the service. In its decision Number 63 Youth Year 2003 explained that the service standard at least include; a standardized service procedure) for the giver and receiver services including complaints; $b$ the specified completion time) since the submission of the application until the completion of the Ministry including complaints; c) service fees, cost/price of the service including the details set out in the process of granting of services; d) product service, the results of the services that will accept in accordance with the provisions of the set; e) infrastructure, the provision of facilities and infrastructure adequate service by public service providers; f) competence service giver officers should be set appropriately based on the knowledge, skills, attitudes, and behaviors that are required.

With respect to the matters mentioned above, a good service will only realized if a) system services that give priority to the interests of the community; b) culture of service in the Organization of service providers, and c) human resource-oriented interests of users of the service (Ratminto and Winarsih, 2009:141). Related to this, then in the concept of public services according to Denhardt and Denhardt (2003) is very complex, with complexity, we have to manage the public organizations that can enhance and encourage including this sort its citizens in all facets and stages of policy-making and implementation process. Therefore, "the public servants, particularly the administrators of the public, have an ethical obligation to expand the boundaries of public participation in the political processes in whatever way they can do" (Denhardt and Denhardt, 2013: 83).

Basic tasks of the State apparatus serving the citizens not to serve customers (Denhard and Denhard, 2003). Therefore, the source of the main ministries in a country is the apparatus of the State. The State is responsible for the public service. Ideally, in a variety of administration theory requirements pertaining to the Ministry of public service, there are several concepts a musthave among others, 1) must be able to assert something means and means that can applied to the situation real life in society (contextual), 2) must be able to present a future perspective; 3 ) should be able to encourage the inception of ways or new methods in different conditions and situations; 4) existing administrative Theory 
should be able to form the basis for developing the theory of other administrations, particularly the public service; 5) should be able to help the wearer to explain and predict phenomena encountered; 6) are multidisciplinary and multidimensional (comprehensive) (Suryono, Accessed December 15, 2015, 2015).

2. The apparatus of the State or the public administrator has the primary responsibility in the public service. The apparatus of the State must build the limits the participation of citizens in providing input in the political process (Denhardt and Denhardt, 2003). About the matter of Stephen k. Bailey giving an interpretation that the administration needs to understand public policy and moral ambiguity, acknowledging moral priorities and Paradox-paradox of public services, and moral qualities include optimism, courage, and honesty (Denhardt and Denhardt, 2013:82)

\section{Management Of Public Service}

Understanding management according to Gibson, Ivancevich \& Donelly (1996) as a process carried out by one or more individuals to coordinate various activities to achieve results that cannot be achieved if one individual Act itself (Ratminto and Winarsih, 2009:2). That is why the success or failure of an organization can be known through the implementation of management functions, with the implementation of management functions that can be properly purposeful activities. According to Dessler (2010:4), there are five basic functions of management, i.e. planning, organizing, staffing, leadership preparation, and control.

With the influence of new public Management in 1980 's and 1990 's, public interest goals based on shared values and a current loss of relevance. New public management is based on the idea that the Government should create area options similar to the market in which individuals, as consumers, can make decisions based on their self-interest ( Denhardt and Denhardt, 2013:212-213).

The Government is carrying out the role of the State as a provider of public services back felt his role when free-market liberalization and the movement is too exaggerated proved unsuccessful embodies the dream of many people that the Affairs of the public services will be much more effective, efficient, responsive, and accountability when provided by private parties. Indeed recognized that the management practices used by business organizations are indeed far more sensitive to the demands of their customers (Anthony, 2009:302).

Good service demands absolute implemented, public services based on the decision of the Minister of State for Administrative Reform Number 63 Years 2003 are all activities carried out by public service providers as an attempt the fulfillment of the needs of the recipient of services as well as the implementation of the provisions of the legislation, which is the organizer of the public service is the Government institutions. The same thing is expressed in the decision of the Youth, in Act No. 2009 25the years of public service, the public service described as an activity or series of activities in the framework of the fulfilment of the needs of the service. Accordance with the legislation for each citizen and resident of goods, services, and/or administrative services provided by the organizer of the public service.

In addition to Government Agency acts as a service provider, "the Government has a moral obligation to ensure that any solution that is generated through the process entirely consistent with the norms of Justice and honesty and achieved through the process that is fully consistent with democratic norms and ethics. The Government will act to facilitate solutions over public issues, but he also will be responsible for ensuring that solutions are consistent with the public interest - both in substance and in process. (Denhardt and Denhardt, 2009:96). Therefore, in the concept of institutional change, adoption of standard implementation service is a stage or a lengthy process through the introduction of new norms to stages of legitimacy, that is when the new norms acceptable to the members of the Organization and be a day to day practices (Anthony,2009:309).

With regards to the description above, there are three traits that mark public service, i.e., the first qualitative difference between activities 
that recognized as public service and activity that comes from the initiative and the purpose of personal or private; Second, the difference in public services this means more important compared to other similar activities, then arranged in particular; third, the public service has a public legitimacy inherent in the power of the State. (Haryatmoko: 2011:13). Therefore, according to "Stephen k. Bailey, the administrators need to understand the moral ambiguity,city of public policy, acknowledging the moral priorities and Paradox-paradox of public services, and moral qualities" 1) 2) optimism, courage, and 3) the honesty that was forged by the generosity (Denhardt and Denhardt, 2009:82). Also, the image of the public service can be seen on the exposure that a public officer or a bureaucrat should be able to provide the best service to the public because it works one of these indicators is determined by how satisfied the community got the Ministry of those (Susanto, 2009:324).

\section{Performance Management}

Performance management is a way to get better results for the organizations, groups, and individuals understand and manage performance by the planned targets, standards and competency requirements specified ( Dharma, 2009:25). The apparatus as a bureaucratic government activity implementers determine results achieved through good performance. According to Tarigan (2005:4). Performance is good when determining a plan or standard that will do. Without a standard then the direction the Organization will meet the starting point deviation. Good planning will find a good direction. According to Friedman's "planning is a way of thinking to tackle social and economic problems, to produce something in the future. The intended target was a collective desire and pursuit of alignment in policies and programs. General purpose performance management is to create a culture of the individual and the group taking responsibility for work process improvement efforts and continuous capability. Performance management process can used for communicating the strategy strengthens the values and norms of the Organization and to integrate individual and organizational goals. Performance management allows individuals to express their views about what they are supposed to do, the direction of which will target and how should they be managed (Dharma, 2009:27). Performance apparatus requires the intellectual maturity, experience, and is responsible for a given activity. Intellectual maturity is determined intelligence, have reasonable and clear-thinking based on a depth of knowledge. Experience is providing reinforcement performance because it never had, melatonin and do the same job. And responsible, one can perform well when can shoulder the burden of work and took away everything that is attached to the apparatus run by the task. About the performance of the bureaucracy, "several studies show that the root problem that is causing the poor performance of the public service is a straightforward procedure and is not transparent and is not accountable (Ratmiko and Winarsih: 2009:205). Related to the performance appraisal shall be "based on the understanding of the knowledge, skills, and behaviors that mastery is required to execute a job well and analysis about the attribute of the person's behavior is appropriate the specified criteria for each job (Dharma, 2009:101). Besides knowledge, skills, and mastery of the necessary behavior, consider the competencies in the recruitment of employees participated also determine due to "technical factors include various competencies, personality and behavior, soft skills and hard skills, and then disseminated as aspects that assessed a lot of companies to recruit employees (Sedarmayanti, 2011:125). Related to the above then the recruitment taking into account competence can be accounted for to achieve good performance. "To be able to meet the requirements of the competence of human resources shall meet the traits or characteristics that is 1) full knowledgeable about duty, responsibility, and authority, 2) have knowledge (knowledges) required, associated with the execution of his duty in full 3) are able to carry out tasks which should be commended for having the expertise/skills (skills) required, 4) Being productive, innovative/creative, willing to work together with others, can trusted, loyal and so forth (Sutrisno: 2010:9). With increasingly 
intense competition faced by organizations today, the role of human resources is crucial in creating a management organization that is efficient, and productive. According to Jeffrey Pfeffer (1994), human resources excellence is a source of competitiveness that can deal with various challenges (Sutrisno, 2010:19). Therefore according to the Sedarmayanti, 2011) a company can gain a competitive advantage when you pay attention to human resources because human resources allow faster learning and apply knowledge more effectively than its competitors ". Therefore, to meet the quality standards for the Organization in achieving the objectives by its vision, then human resources competence requirements must be observed.

\section{Research result}

\section{State Government Employees District Majene}

The number of civil servants (PNS) that Majene District Government data quarterly Porziuncola 54802014 III in person. Of these employees are male-sex amounted to 2,643 people and women-sex amounted to 2,837 people.
To clarify the circumstances of the employees either civil servants or employees of the privately owned by County Government Majene good judging from the level of education, groups, and non-Echelon Echelon. As for State Government employees can Majene District described as follows :

\section{a. Education}

A civil servant at the District level education as seen from Majene, owned by employees can be said to be quite good. Secondary data from search results found that the average level of education civil servant (PNS) is quite good because the employees are generally well educated above high school reached $73 \%$. Judging from the level of education of those employees then it can be specified that an educated officer $>$ Bachelor is 44 percent or outsiders to 2.395, D I-D III amounted to 1579 people or 29 percent, and SD-SMU totaled 1506 people or 27 percent.

To further clarify the educational qualifications of civil servants can be seen on the chart on page 18

Table 1. Education-level civil servant (PNS) specified based on gender.

\begin{tabular}{|l|l|l|l|l|}
\hline \multirow{2}{*}{ Level of Education } & \multicolumn{2}{|l|}{ Gender } & $\begin{array}{l}\text { The total } \\
\text { number of }\end{array}$ & Percent \\
\cline { 2 - 5 } & Pria & Wanita & & \\
\hline $\begin{array}{l}\text { < High School (SD- } \\
\text { SMU) }\end{array}$ & 914 & 592 & 1506 & 27 \\
& $60.69 \%$ & $39.31 \%$ & $100 \%$ & \\
\hline Dipl. I s/d Dipl. III & 511 & 1068 & 1579 & 29 \\
\hline $\begin{array}{l}> \\
\text { degree (S1) }\end{array}$ & $32,36 \%$ & $67.64 \%$ & $100 \%$ & \\
\hline The total number of & 2643 & 1177 & 2395 & 44 \\
& $48,23 \%$ & $51,77 \%$ & $100 \%$ & \\
\hline
\end{tabular}

Source: office of The Agencies Staffing Offices Majene district (September 2015, Processed)

The line of civil servants Regency

b. The Line Of Government Majene scattered in various agencies and institutions have the amount 
varied from one group to the other. The number of the employee who most based on secondary data owned by the Group III with a total of 2103 or 45.02 percent, following the II with a population of 2109 or 33.20 percent, IV 1126 or 19.34 percent, and the last group I with a total of 142 people or 2.44 percent.

Based on search data through Staffing Agencies Offices, that of the amount of the employee group 1126 IV Table 2. The civil servant (PNS) specified by gender.

\begin{tabular}{|c|c|c|c|c|}
\hline \multirow[t]{2}{*}{ The Line Of } & \multicolumn{2}{|l|}{ Gender } & \multirow[b]{2}{*}{$\begin{array}{l}\text { The total } \\
\text { number of }\end{array}$} & \multirow[b]{2}{*}{ Percent } \\
\hline & $\begin{array}{l}\text { Men } \\
(\%)\end{array}$ & $\begin{array}{l}\text { Women } \\
(\%)\end{array}$ & & \\
\hline IV & $\begin{array}{l}505 \\
44,85 \%\end{array}$ & $\begin{array}{l}621 \\
55,15 \%\end{array}$ & $\begin{array}{l}1126 \\
100 \%\end{array}$ & 20.55 \\
\hline III & $\begin{array}{l}1055 \\
50,17 \%\end{array}$ & $\begin{array}{l}1048 \\
49.83 \%\end{array}$ & $\begin{array}{l}2103 \\
100 \%\end{array}$ & 38.37 \\
\hline II & $\begin{array}{l}978 \\
46.37 \%\end{array}$ & $\begin{array}{l}1131 \\
53.63 \%\end{array}$ & $\begin{array}{l}2109 \\
100 \%\end{array}$ & 38.49 \\
\hline I & $\begin{array}{l}105 \\
73.94 \%\end{array}$ & $\begin{array}{l}37 \\
26.06 \%\end{array}$ & $\begin{array}{l}142 \\
100 \%\end{array}$ & 2.59 \\
\hline The total number of & $\begin{array}{l}2643 \\
48.23 \%\end{array}$ & $\begin{array}{l}2837 \\
51.77 \%\end{array}$ & $\begin{array}{l}5480 \\
100 \%\end{array}$ & 100 \\
\hline
\end{tabular}

Source: Office Of The AGENCIES STAFFING OFFICES Majene district (September 2015, Processed)

Based on the above, the table shows that employees of the dominant women-sex on the IV and II and III have a balance. But on the men, I was very dominant, i.e., $94 \%, 73$.

\section{c. Structural and functional Office}

Research data shows that the civil servant who occupied the position of structural-sex men sex women compared with far more on all levels of Office starting from the position of Echelon IV up to Echelon II.

At the Office of Echelon II 33 of those civil servants who reinstated more dominated by females, i.e. $55.15 \%$ or 621 persons and men's 505 people. At the III composition can be balanced, i.e., women 1048 or $49.83 \%$ and men 1055 or $50.17 \%$. For the number of women more II, i.e. $113153.63 \%$, and people or to the I number of men is much greater than the number of women that is 105 persons or $73.94 \%$ men and women of 37 people or $26.06 \%$. 
Table 3. Structural position (Echelon), civil servants specified based on gender.

\begin{tabular}{|l|l|l|l|l|}
\hline \multirow{2}{*}{ Echelon } & Gender & Wanita & Total & \multirow{2}{*}{ Percent } \\
\cline { 2 - 5 } & Men & 5 & 34 & 5,27 \\
\hline II & 29 & 14,71 & 100 & \\
\hline III & 85,29 & 36 & 131 & 20,31 \\
& 95 & 27,48 & 100 & \\
\hline IV & 72,52 & 160 & 470 & 72,87 \\
& 310 & 34,05 & 100 & \\
\hline V & 65,95 & 2 & 10 & 1,55 \\
& 8 & 20 & 100 & \\
\hline The total number of & 40 & 203 & 645 & 100 \\
& 64,53 & 31,47 & 100 & \\
\hline Non-Echelon & 2643 & 2837 & 5480 & - \\
\hline
\end{tabular}

Source: office of the agencies staffing offices Majene district (September 2015, Processed)

\section{d. The Functional Position}

In contrast to the position of structural, functional Office on the number of women far more than men. It evidenced in the education service of the number of people occupying the Office of 2692 functional there are 1654 women or $61 \%$ of men and $39 \%$ of people or 1038. In BPD-PMPKB 36 people who occupied the post of functional, there are 30 people or $83.33 \%$ female-sex or 30 people who occupied the post of a gentleman and functional eight people or $16.67 \%$. Some employees who occupied the position of a functional on a Department of agriculture amounted to 73 people, there were 54 people, or $73 \%$ occupied by males and 19 persons or $26.03 \%$ occupied by women. On health service of 310 employees who occupied the post of functional, there are 251 men or women $80.97 \%$ and men 59 persons or $19.03 \%$. At the General Hospital Area of 131 employees who occupied the post of functional, there is 98 people or $74.81 \%$ of women occupying the position of men and 33 people or $25.19 \%$. And the Office of the Inspectorate of the eight employees who occupied the post of functional there is five people or $62.5 \%$ of the men and women of 3 persons or $37.5 \%$. From these data only at the Office of the Department of agriculture are striking predominance of men much larger compared to women. According to the analyses and observations of one factor is the functional term in agriculture much more in the field so that women's low interest, with different men that love to work in the field. To further clarify the differences between men and women held in functional can seen in the following table.

Table 4. The functional position of civil servants also based on gender.

\begin{tabular}{|l|l|l|l|l|}
\hline \multirow{2}{*}{$\begin{array}{l}\text { The Functional } \\
\text { Position }\end{array}$} & \multicolumn{2}{|l|}{ Gender } & \multirow{2}{*}{ Total } & \multirow{2}{*}{ Percent } \\
\cline { 2 - 3 } & Men & Women & \\
\hline Office Of & 1038 & 1654 & 2692 & \\
Education & $39 \%$ & $61 \%$ & $100 \%$ & \\
\hline BPD-PMPKB & 6 & 30 & 36 & 1,10 \\
\hline
\end{tabular}




\begin{tabular}{|l|l|l|l|l|}
\hline & $16,67 \%$ & $83,33 \%$ & $100 \%$ & \\
\hline $\begin{array}{l}\text { Department Of } \\
\text { Agriculture }\end{array}$ & 54 & 19 & 73 & 2,25 \\
\hline Health Service & $59,97 \%$ & $26,03 \%$ & $100 \%$ & \\
& $19,03 \%$ & 251 & 310 & 9,54 \\
\hline Regional General & 33 & $98,97 \%$ & $100 \%$ & \\
Hospital & $25,19 \%$ & $74,81 \%$ & 131 & 4,03 \\
\hline The Inspectorate & 5 & 3 & 8 & 0,25 \\
& $62,5 \%$ & $37,5 \%$ & $100 \%$ & \\
\hline The total number of & 1.526 & 1,805 & 3250 & 100 \\
\hline
\end{tabular}

Source: Office Of The AGENCIES STAFFING OFFICES Majene district (September 2015, Processed)

\section{The structure of the Agency's Staffing and Training Area}

Agency Staffing and Training Area established by applicable local County Majene Number 14 in 2008. In the area of Regulation No. 14, explained that the Agency's staffing and Training Area is one of the devices is the work or Government agencies that carry out the Affairs of the regional autonomy in the areas of employment and education practice. In article 67 of the regulation region number 14 in 2008 about the Agency's staffing and Training areas in Staffing Agency Organization describe and Training areas consist of :

a. The head of the

b. Secretary consisting of Sub. Part of planning, Evaluation, and reporting; Public Subsections and Staffing; Sub Part Of The Financial

c. The field of Formation and Staffing information system consisting of a Sub. Areas of planning Formation and selection; Sub Field Of Data Information Systems Clerk.

d. The Mutations field consists of Sub Field placement and dismissal of Employees; Sub Field Line.

e. Tekknis functional Training areas consist of Training Technical Subfields; Sub Field Of Functional Training

f. The field of Structural and management training was composed of Sub areas of training: Penjenjangan; Sub Field Of Training Public Education

As for the duties and functions of each of the above structures are outlined as follows::

1. The head of the

The head of Agency leads agency Staffing and Training Area with the task of assisting the head of the principal areas of staffing authority in the field of organizing and training the region based on the principle of autonomy and assistance accordance with the Affairs a Government that becomes regional and the authority or upon conditions. In the basic tasks of the head of the Agency has the function of coordinating, directing, guiding, nurture and empower a management unit of work elements of the regional staffing field devices and training areas.

The function that is run by the head of the agency include a) formulation of annual work programmes, Renstra, program long-term and medium-term program and operational instructions, guidelines, and technical instructions authorizes execution of field personnel and training areas; b) organizing strategic plan; c) implementation strategic plan; d) control and monitoring of the implementation of the strategic plan; e) evaluation of the implementation of strategic plan; f) report preparation stakeholders strategic plan; g) the giving 
of advice and technical considerations to superiors about the implementation of the annual work programme, strategic plan, formulation of annual work programmes, strategic plan program long-term and medium-term program and operational instructions, guidelines and technical implementation authority staffing training and areas of the region; $h$ ) the implementation of the basic tasks and functions of managing technical units; I) implementation of the other tasks given by the leadership of the region.

\section{Secretariat}

The Agency Secretariat headed by a Secretary has a duty of helping the head of the Agency's conduct or facilitate coordination and implementation authority staffing training and areas of area-related affairs within the Organization include planning, evaluation, reporting, administrative and financial management services. The principal task of conducting functions help coordinate and facilitate a working device units management elements of the regional staffing and field training area.

3. The field Formations and Personnel information system

The field of formation and information systems personnel led by a head of a field that has the basic tasks of helping the head of the Agency in preparing, gather and cultivate and carry out activities in the field of formation and personnel information systems. The principal task in the head of the formation has the function of helping coordinate and facilitate activities in the field of formation and staffing systems.

\section{The Field Of Mutation}

The field of Mutations has basic tasks helping to head the Agency in preparing, gather and cultivate and carry out activities in the field of mutations. Basic tasks in the head of the mutation have a function helps coordinate and facilitate activities on the field or a mutation that includes a) the planning and conduct of the Affairs of Government and public service in the field of mutation; b) coaching and carry out activities in the field of mutation; c) Pengkoordinasian organization programs and activities in the field of mutation; d) implementation monitoring and evaluation of programmes and activities; e) implementation monitoring and inventory problems that relate to the field of duty and prepare ingredients instructions troubleshooting; f) report preparation task results and give consideration to suggestions employer match field of duty; g) implementation other tasks assigned by superiors according to the field of duty.

5. The Field Of Functional Technical Training

The field of Functional Technical Training led by a head of a field that has the basic tasks of helping the head of the Agency in preparing, gather and cultivate and carry out activities in the field of technical training, functional. The head of the field in their job functions help coordinate and facilitate or activity in the field of technical, functional training which includes: a) the preparation of the data/materials in the framework of functional, technical training needs analysis; $\mathrm{b}$ technical policy assignment) field of functional, technical training; c) planning and conduct of the Affairs of Government and public service in the field of functional, technical training; d) coordinating organizing programs and activities in the field of functional, technical training; e monitoring and evaluation) program and activities; f) implementation monitoring and inventory problems that relate to the field of duty and prepare ingredients instructions troubleshooting; g) report preparation task results and give consideration to suggestions employer 
match field of duty; h) implementation other tasks assigned by superiors according to the field of duty.

6. The field of Structural and Management Training

The field of Structural and management training led by the head of the field that has the basic tasks of helping the head of the Agency in preparing, gather and cultivate and carry out activities in the field of structural and management training.

In carrying out the duties of principal Chief of the field, functions help coordinate and facilitate activities in the field of structural and management training that includes :

a) formulation of technical activities in the field of structural and management training as well as general education;

b) the planning and conduct of the Affairs of Government and public service in the field of structural and management training as well as general education;

c) coordinating the implementation of activities in the field of structural and management training as well as general education;

d) the implementation of coordination, monitoring, and evaluation of organizing programs and activities in the field of structural and management training as well as general education;

e) the implementation of the monitoring programs activities;

f) implementation of the monitoring and inventory problems that relate to the field of duty and prepare ingredients instructions troubleshooting;

g) report preparation task execution results and consider suggestions employer match field of duty; h) implementation other tasks assigned by superiors according to the field of duty.

\section{The Ministry of civil service Bodies and Apparatus Training Areas}

One of the basic tasks of the Agency's Staffing and Training Area is serving the interests of local government employees which include the Ministry of promotion, salary increases periodically employees, service employees who entered full-time service or retirement, and service training: employees who do not yet exist established as guidelines in providing the service.

Based on observations and interviews with the officials of the local government County of Majene that finished and in the process of the settlement the Administration promoted generally give answers that the implementation process administrative staffing goes smoothly, but in the completion of any administration is not clear. One of the factors the lack of clarity is the operational standards of service (SOP) that does not exist, so the guidelines in providing the service there is no certainty.

To specify a certainty in any administrative service, one of the factors that need to prepared is the operational standards of service (SOP), as with the standard service administration (SOP) can provide the certainty of the settlement the Administration and justice in the sense of receiving service. The principle of Justice in the service of absolutely do. The concept of Justice has the meaning of how State authorities in providing services do not differentiate between one resident with other citizens, because of family factors, ethnicity, and religion. Because after all the communities they serve have the same rights as citizens.

Determination of the operational standards of service (SOP) on the staffing Agency offices and Training Areas there is an absolute must. Office Agencies Staffing Offices is the central administrative service personnel in the district began at the time of an Employee as a potential employee, a civil 
servant appointed as civil servants, employees at the time of taking care of the promoted officers, at the time of taking care of the administration of the pension. To be able to give you the satisfaction of service, then the standard procedure of service activities to followed by the waiter (apparatus) in providing service to interested parties need to be set.

Based on the results of the study, it found that the process of administrative service in the offices of Agencies Staffing Offices is quite good, the employees in delivering the information connected with the Affairs of every employee is quite clear, has hospitality, but in specify the time of the affair finished there is still uncertainty as to when the finished paperwork. One factor that made it happen, because in the offices of Agencies Staffing Offices do not have the SOP. If the Office Staffing Agencies Offices have operational standards of service (SOP), then the period of completion of an affair can know. Operational standards of service (SOP) is obvious. Namely, there is clarity of time, cost and other requirements that must be met by every employee who will serve. With the existence of an SOP between servant and served each one knowing the standard services so that every apparatus in completing the paperwork see.

Operational standards of service (SOP) personnel who have not been made by the Agency's staffing and Training Areas affect the performance of employees in completing each job and wait time is the person served has no clear certainty. With the uncertainties of the time, their every moment came in the Office Staffing Agencies Offices ask when their affair ended. This condition makes the employees feel dissatisfaction, loss of time and costs enough to be felt. An employee of the place of residence not far from the capital of the County is not too feel the loss costs, but those who are his in remote area village very feel the loss cost the cost and time because they have to stay a few days waiting for the certainty of the affair is finished.
Based on direct observations and interviews with officials at the Agency's staffing and Training Area that there is no defined staffing SOUP in a letter decision, but the Ministry according to their work and provide the information referred to regarding legislation and other regulations that govern about staffing.

The intensity of activity and Staffing Agency employee apparatus Training Areas have the volume of activity that is pretty solid. Judging from the number of apparatus which perform services was disproportionate to the volume of activities that they are working on. The type of service that has a pretty solid volume of activities includes the promotion officer, the making of the decision letter of the mutation and the service to the employees who entered full-time service or retirement.

Service promotion officers in Majene in annually conducted in two periods, i.e. April and October period. Before the promotion period employees were implemented in advance of the Agency's Staffing and Training the region delivered a letter request to the data Service Agencies ministries and Regional institutions employees can be promoted is proposed. Request for proposal the promotion done by the Agency's staffing and Training area to any Service-Service area and Regional agencies three months before the proposal submitted to the Agencies Staffing Offices.

In cracking down on transmitted requests it, Office-Office and Regional Agencies pass on to employees in the respective environment. To realize the demand for the Agency's staffing and Training Area, the head of The respective Area of work verifying Device or data searches of every employee. The data from the search results, an eligible employee of a mailing address to complete the administrative requirements needed.

From the results of a report from the Office and the institutions, offices and staffing agencies to verify further back and match the existing data on the staffing agencies offices, after the completion of the verification data 
delivered back a letter to Agencies and ministries Department Institutions for further processed from the respective ministries and agencies Office of the region where the place of employees promoted that will process. Based on the proposals of each instance of that apparatus agencies staffing offices, verifying the end of data or files that will submit to the governing body of the State administration of civil service in Majene.

\section{Conclusion}

Based on observations and interviews with the officials of the local government County of Majene that finished and in the process of the settlement the Administration promoted generally give answers that the apparatus is in the run the task pretty well, but in the completion of any administration is not clear. One of the factors affecting the obscurity that, because Agencies Staffing Offices do not yet have an operational service standard (SOP) in providing service.

In the absence of SOP makes employees feel the loss of time and cost. An employee of the place of residence not far from the capital of the County is not too feel the loss costs, but they are his away was in remote corners of the village greatly feel the loss cost and time, because they have to daily come, If they don't come, they stay a few days at the family home in the city of Majene in case they don't have their families stay at a hotel or lodging, waiting for the certainty of the affair is finished.

\section{References}

[1]Denhardt, J.V. dan Denhardt, R.B. 2003. The New Publik Service, M.E. Sharpe, New York

[2]Dharma, S. 2009. Manajemen Kinerja Falsafah Teori dan Penerapannya, Pustaka Pelajar, Yogyakarta.

[3]Haryatmoko, 2011, Etika Publik Untuk Integritas Pejabat Publik dan Politisi, Gramedia Pustaka Utama, Jakarta
[4] Keban, Yeremis.T 2008. Enam Dimensi Strategis Administrasi Publik Konsep, Teori dan Isu (Edisi 2), Penerbit Gavamedia, Yogyakarta.

[5] Menpan, 2003. Kepmenpan Nomor 63 Tahun 2003 tentang Pedoman Pelayanan Publik.

[6] Menpan , 2009. Undang-Undang Nomor 25 Tahun 2009 tentang Pelayanan public

[7] Puspita, D.R. 2004. Reformasi Birokrasi Publik. Kajian Tentang Kinerja Aparat Kecamatan Purbalingga Dalam Era Otonomi Daerah," Visi Publik Jurnal Ilmu Administrasi Publik Volume 1 Nomor 1, April 2004. Jurusan Ilmu Administrasi Negara Fakultas Ilmu Sosial dan Ilmu Politik Universitas Jenderal Sudirman, Purwokerto.

[8] Purwanto, E.A.,2009. Strategi Penerapan Standar Pelayanan Untuk Reformasi Birokrasi, dalam"Reformasi Birokrasi, Kepemimpinan dan Pelayanan Publik (Editor Agus Pramusinto dan Erwan Agus Purwanto), Gava Media, Jian UGM-MAPUGM, Yogyakarta.

[9] Ratminto dan Winarsih, 2009. Manajemen Pelayanan Pengembangan Model Konseptual,Penerapan Citizen's Charter dan Standar Pelayanan Minimal, Pustaka Perlajar, Yogyakarta

[10] Robins,Stephen P., dan Judge, Timothy A., 2008. Perilaku Organisasi Buku" I Penerjemah Diana Angelica, Salemba 4, Jakarta

[11] Subarsono, A.G. 2006. Pelayanan Publik Yang Efisien, Responsif dan Non Partison, Gadjah Mada University Press, Yogyakarta

[12] Sugiono, 1998. Metode Penelitian Administrasi, Alpabeta, Bandung

[13] Susanto,E., 2009. Kecerdasan Emosional Birokrat dan kinerja Pelayanan Publik, Dalam "Reformasi Birokrasi, Kepemimpinan dan Pelayanan Publik (Editor Agus Pramusinto dan Erwan Agus Purwanto), Gava Media, Jian UGM-MAPUGM, Yogyakarta. 
Indonesia Prime, p-ISSN: 2548-317X, e-ISSN: 2548-4664

Vol. 2, No 1, November 2017, pp. 01-13

[14] Sutrisno, E. 2010. Manajemen Sumber Daya Manusia, Kencana Prenada Media Group, Jakarta

[15] Suryono, A. 2015. Budaya Birokrasi Pelayanan Publik, Kemenkumham (online) Diakses 15 Desember 2015

[16] Sedarmayanti, 2011. Manajemen Sumber Daya Manusia Reformasi Birokrasi dan Manajemen Pegawai Negeri Sipil, Refika Aditama, Bandung

[17] Tarigan, R., 2005. Perencanaan Pembangunan Wilayah (edisi Revisi), Bumi Aksara, Jakarta 